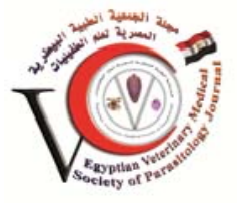

Original Article

\title{
The prevalence of the helminth parasites of stray dogs in Ismailia City
}

Asmaa M.I. Abuzeid ${ }^{1 *}$, Eman M. Youssef ${ }^{1}$, Ahmed A. Abdel Aal $^{1}$, Hamdy M. El-Gawady ${ }^{1}$

${ }^{1}$ Department of Parasitology, Faculty of Veterinary Medicine, Suez Canal University

*Corresponding author.

Asmaa M.I. Abuzeid

Tel.: +2 01094578925.

E-mail address:

asmaa_ibrahim@vet.suez.edu. eg

\begin{abstract}
:
In a study on the parasites of stray dogs in Ismailia City, 50 stray dogs of different sexes and ages were humanely euthanized, necropsied, and examined for helminth parasites. Twenty helminths (14 trematodes, two cestodes, and four nematodes) were detected. The total prevalence of helminths was $100 \%$, with trematodes $(36 \%)$, cestodes $(100 \%)$, and nematodes (34\%). Of the recorded 14 trematodes, Pygidiopsis summa and Ascocotyle rara were recorded for the first time in Ismailia Province and might be for the first time among Egyptian dogs. The most prevalent trematode was Pygidiopsis genata (20\%). The detected cestodes were Dipylidium caninum (100\%) and Taenia hydatigena (10\%). The recovered nematodes were Toxocara canis (20\%), Toxascaris leonina (10\%), Spirocerca lupi (10\%), and Rictularia affinis (8\%). There was a highly significant difference $(p<0.01)$ in the prevalence of trematodes between different ages $(60 \%$ in adults and $0 \%$ in young dogs). The prevalence of Toxocara canis was significantly higher $(p<0.05)$ in young dogs $(40 \%)$ than in adult ones $(6.7 \%)$. There was no significant difference $(p>0.05)$ in the prevalence of the detected helminths with the sex of dogs. Histopathological examination of the lungs and oesophagus of dogs infected with Spirocerca lupi revealed chronic pneumonia, pulmonary alveolar emphysema, granulation tissue formation, and an early stage of fibroma in the oesophagus. All necropsied dogs were infected with at least one zoonotic helminth parasite. In conclusion, stray dogs in Ismailia City carry several helminth parasites, thus posing a risk for both human and companion dog populations.
\end{abstract}

Key words: helminth, stray dogs, Ismailia, and prevalence

\section{INTRODUCTION}

The dog population in urban and suburban regions comprises dogs that roam only with their owners and stray and ownerless dogs that roam sporadically (Beck, 2000). Of the estimated 500 million dogs worldwide, about 400 million are stray ones (WSPA, 2009). Egypt has a large population of stray dogs that move freely within cities and contact other urban, suburban, and rural animals (Nabih, 1998). Dogs are associated with more than 60 zoonotic diseases, among which parasites, in particular helminthiasis, can pose serious health concerns (Rhindali etal., 2006) as well as significant economic impacts froma veterinary standpoint. Dogs play a pivotal role as parasite bridges between wildlife and humans (Salb et al., 2008).

Among zoonotic helminths that can infect dogs, Toxocara canis is particularly pathogenic to humans (McManus, 2006). This nematode can cause visceral larva migrans (VLM), ocular larva migrans (OLM), or both in humans, especially children (Gavignet et al., 2008). The human population in Ismailia City relies heavily on freshwater fish grown in aquaculture systems as a source of dietary protein. Numerous free-roaming dogs scavenge offal from fish farms and become infected by trematodes that utilize fish as an intermediate host. This trematode infection may also be transmissible to humans (Chai et al., 1986a; Chai and Lee, 1990). Canine trematodes in Egypt include Mesostephanus spp., Echinochasmus spp., Heterophyes spp., and Pygidiopsis genata (El-Gayar, 2007). The distribution and intensity of parasitic diseases are influenced by climatic, geographical, cultural, and economic factors. Therefore, studying the helminth parasites in every given region is necessary.

The present work aims to study the prevalence and intensity of the helminth parasites in stray dogs in Ismailia City and discuss the zoonotic risk associated with these dogs. 


\section{Materials AND Methods}

This study was conducted on 50 stray dogs ( 23 male and 27 female) captured from Ismailia City. Their sex and age were recorded. Dogs less than one year were classified as youngs $(n=20)$ and those over one year as adults $(n=30)$. These dogs were humanely euthanized, necropsied, and examined for helminth parasites. At necropsy, exploration of the abdominal and thoracic cavities for the presence of extraintestinal parasites was carried out. The digestive tract and other organs (brain, lung, heart, liver, and urinary bladder) were separately examined. Each part of the alimentary canal was opened in a separate petri dish containing physiological saline. The intestinal contents were washed and inspected by the naked eye and then under a stereoscopic microscope for helminth parasites. The collected helminths were counted according to Bwalya (2012). Trematodes and cestodes were stained with Acetic Acid Alum Carmine, while nematodes were clarified with lactophenol. Then, we prepared permanent mounts from these helminths according to the method of Fleck \& Moody (1993). The collected helminths matched the descriptive data and figures given by Yamaguti $(1939,1958)$, Fahmy and Selim (1959), Soulsby (1982), Nabih (1998), and El-Gayar (2007). Specimens from the lungs and nodules in the oesophagus of Spirocerca lupiinfected dogs were fixed in $10 \%$ formol saline, embedded in paraffin, cut $5 \mu \mathrm{m}$ thick, and stained with H\&E stain (Drug et al., 1967). Chi-square test (Snedecor \& Cochran, 1991) was used to analyze the categorical data and evaluate the statistically significant associations between the prevalence
Table 1: Prevalence of helminths in stray dogs in Ismailia City

\begin{tabular}{lcc}
\hline Helminthes & $\begin{array}{c}\text { No. of infested/ } \\
\text { no. of examined }\end{array}$ & Prevalence \% \\
\hline Trematodes & $18 / 50$ & 36 \\
Cestodes & $50 / 50$ & 100 \\
Nematodes & $17 / 50$ & 34 \\
Total & $50 / 50$ & 100 \\
\hline
\end{tabular}

of helminths and the dog's age and sex. Differences were considered significant at ( $p \leq 0.05)$.

\section{RESULTS}

Parasitological results:

The total prevalence of helminths was $100 \%$, with trematodes (36\%), cestodes (100\%), and nematodes (34\%) (Table 1). All detected parasites (Figs. 1-32) were found in the small intestine except for Spirocerca lupi, which was found in the oesophagus. Fourteen trematode species were recorded. The most prevalent trematode was Pygidiopsis summa (4\%), while Mesostephanus spp. had the highest mean intensity of 95.5 (18-170). Two cestodes (Dipylidium caninum and Taenia hydatigena) were detected. Dipylidium caninum was the most prevalent cestode (100\%) with a mean intensity of 62.3 (2-189) worms/dog. Four nematodes (Toxocara canis, Toxascaris leonina, Spirocerca lupi, and Rictularia affinis) were recovered. Toxocara canis was the most common nematode (20\%) with a mean intensity of 7.3 (3-15) worms/dog (Table 2).

Table 2: Prevalence and intensity of helminth parasites in stray dogs in Ismailia City

\begin{tabular}{|c|c|c|c|c|}
\hline Species & $\begin{array}{l}\text { No. of infested/ no. of } \\
\text { examined }\end{array}$ & Prevalence (\%) & $\begin{array}{l}\text { Intensity } \\
\text { (range) }\end{array}$ & $\begin{array}{l}\text { Mean intensity } \\
\text { (worms/dog) }\end{array}$ \\
\hline Prohemistomum vivax & $2 / 50$ & 4 & $1-5$ & $3.0(6 / 2)$ \\
\hline Mesostephanus appendiculatus & $8 / 50$ & 16 & & \\
\hline Mesostephanus melvi & $3 / 50$ & 6 & $18-170$ & $95.5(764 / 8)$ \\
\hline Mesostephanus sp. & $1 / 50$ & 2 & & \\
\hline Echinochasmus liliputans & $8 / 50$ & 16 & $10-36$ & $19.0(158 / 8)$ \\
\hline Pygidiopsis genata & $10 / 50$ & 20 & $10-40$ & $267(267 / 10)$ \\
\hline Pygidiopsis summa & $3 / 50$ & 6 & $10-40$ & $20.1(20 / / 10)$ \\
\hline Ascocotyle rara & $2 / 50$ & 4 & $2-4$ & $3.0(6 / 2)$ \\
\hline Phagicola longus & $3 / 50$ & 6 & $2-10$ & $5.7(17 / 3)$ \\
\hline Phagicola longicollis & $2 / 50$ & 4 & $1-3$ & $2(4 / 2)$ \\
\hline Metagonimus yokogawai & $2 / 50$ & 4 & $2-3$ & $2.5(5 / 2)$ \\
\hline Haplorchis pumilio & $3 / 50$ & 6 & $2-4$ & $3.0(6 / 2)$ \\
\hline Dipylidium caninum & $50 / 50$ & 100 & 2-189 & $62.3(3116 / 50)$ \\
\hline Taenia hydatigena & $5 / 50$ & 10 & $1-4$ & $2(10 / 5)$ \\
\hline Toxocara canis & $10 / 50$ & 20 & $3-15$ & $7.3(73 / 10)$ \\
\hline Toxascaris leonina & $5 / 50$ & 10 & $2-8$ & $4.4(22 / 5)$ \\
\hline Spirocerca lupi & $5 / 50$ & 10 & $3-8$ & $5.6(28 / 5)$ \\
\hline Rictularia affinis & $4 / 50$ & 8 & $1-2$ & $1.8(7 / 4)$ \\
\hline
\end{tabular}




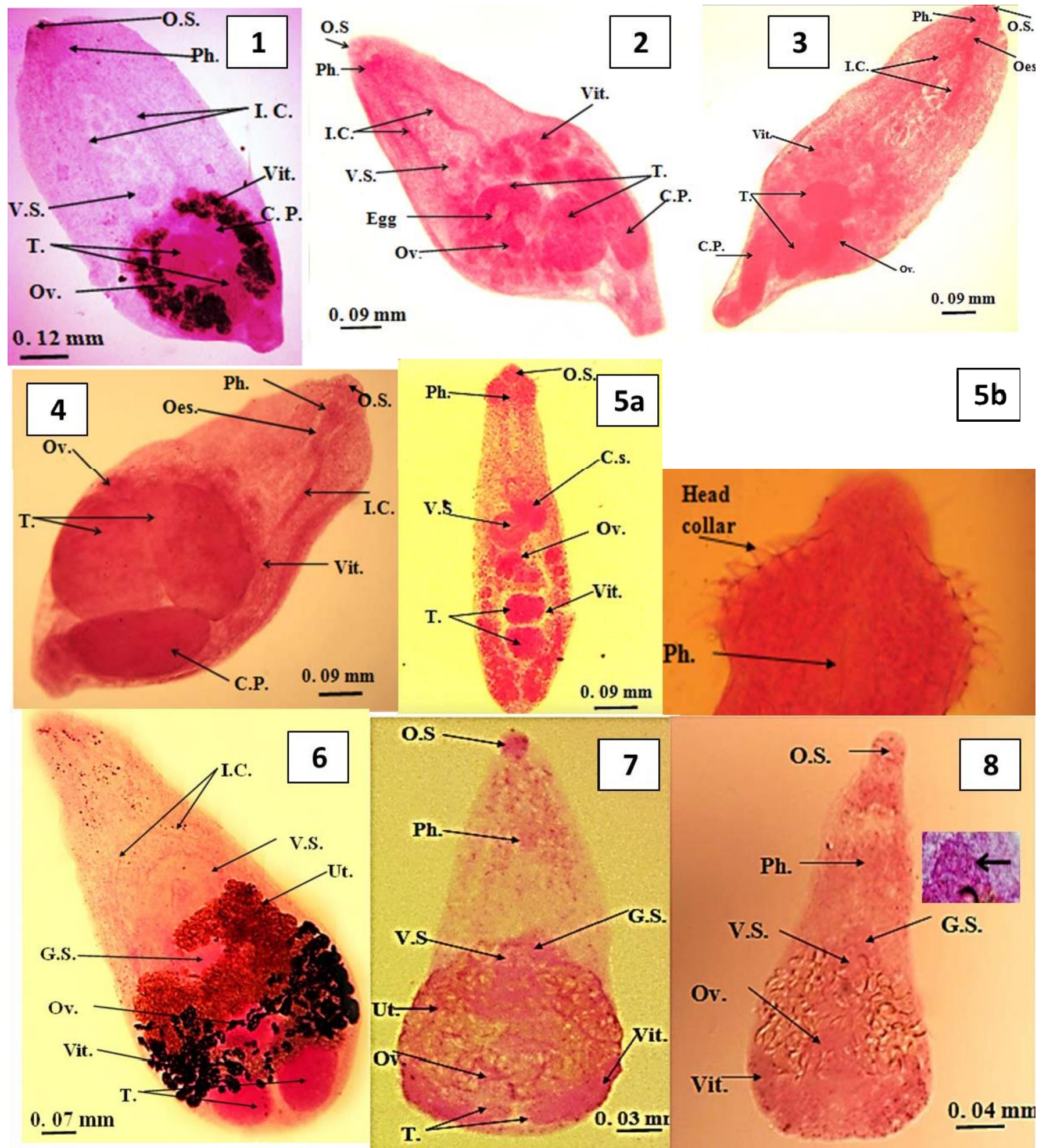

Figure 1-8: Trematodes of stray dogs in Ismailia City

1: Prohemistomum vivax adult,

2: Mesostephanus appendiculatus adult,

3: Mesostephanus melvi adult,

4: Mesostephanus sp. adult,

5a: Echinochasmus liliputans adult, 5b: E. liliputans anterior end,

6: Heterophyes dispar adult,

7: Pygidiopsis genata adult,

8: Pygidiopsis summa adult arrow showing spines on the genital sucker.

(O.S.: oral sucker, V.S.: ventral sucker, Ph.: Pharynx, P. Ph.: pre-pharynx, Oes.: oesophagus, T.: testis, Ov.: ovary, Vit.: vitellaria,

I.C.: intestinal ceci, C.P.: cirrus pouch, G.S.: genital sucker and C.S.: cirrus sac). 


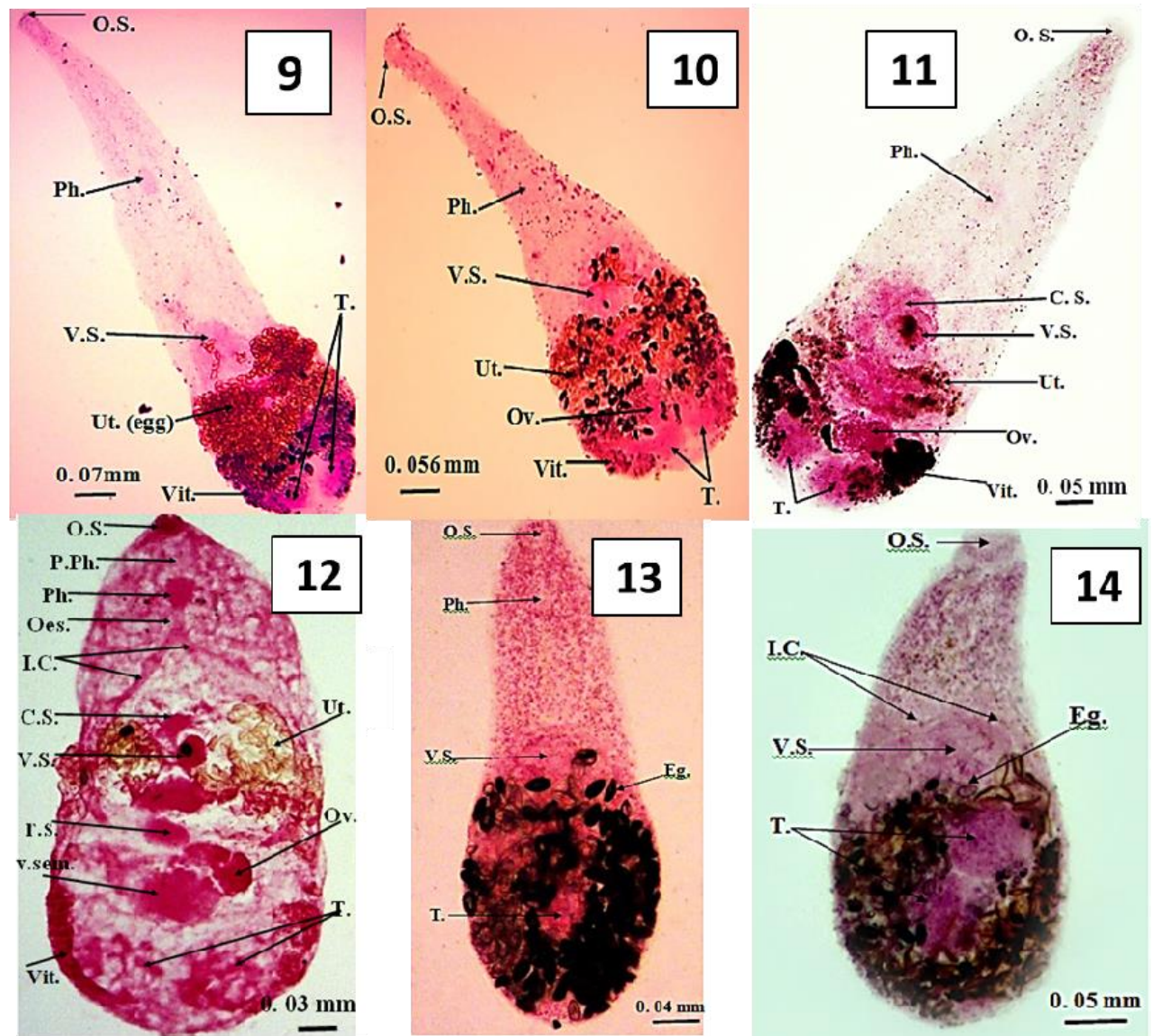

Figure 9-14: Trematodes of stray dogs in Ismailia City 9: Ascocotyle rara adult, 10: Phagicola longus adult,

11: Phagicola longicollis adult,

12: Metagonimus yokogawai adult,

13: Haplorchis pumillio adult,

14: Apophallus donicus adult

(C.S.: cirrus sac, Ut.: uterus, v. sem.: vesicula seminalis, r.s.: receptaculum seminis and Eg.: Egg).

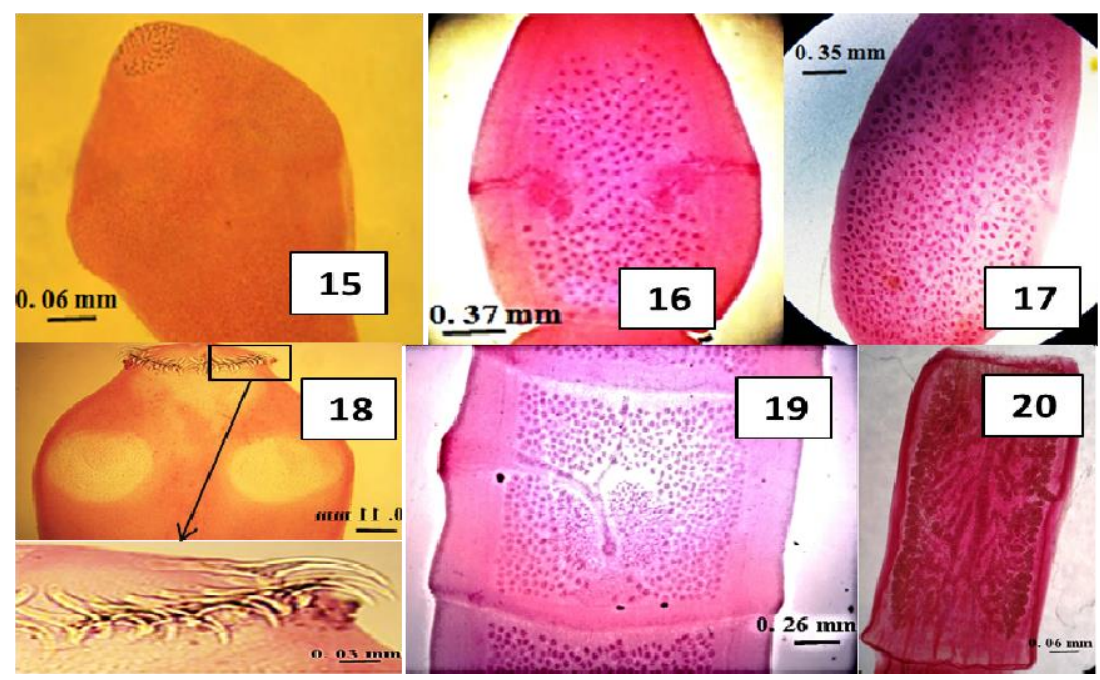

Figure 15-20: Cestodes of stray dogs in Ismailia City

15: Dipylidium caninum scolex,

16: Dipylidium caninum mature segment

17: Dipylidium caninum gravid segment

18: Taenia hydatigena scolex

19: Taenia hydatigena mature segment

20: Taenia hydatigena gravid segment 


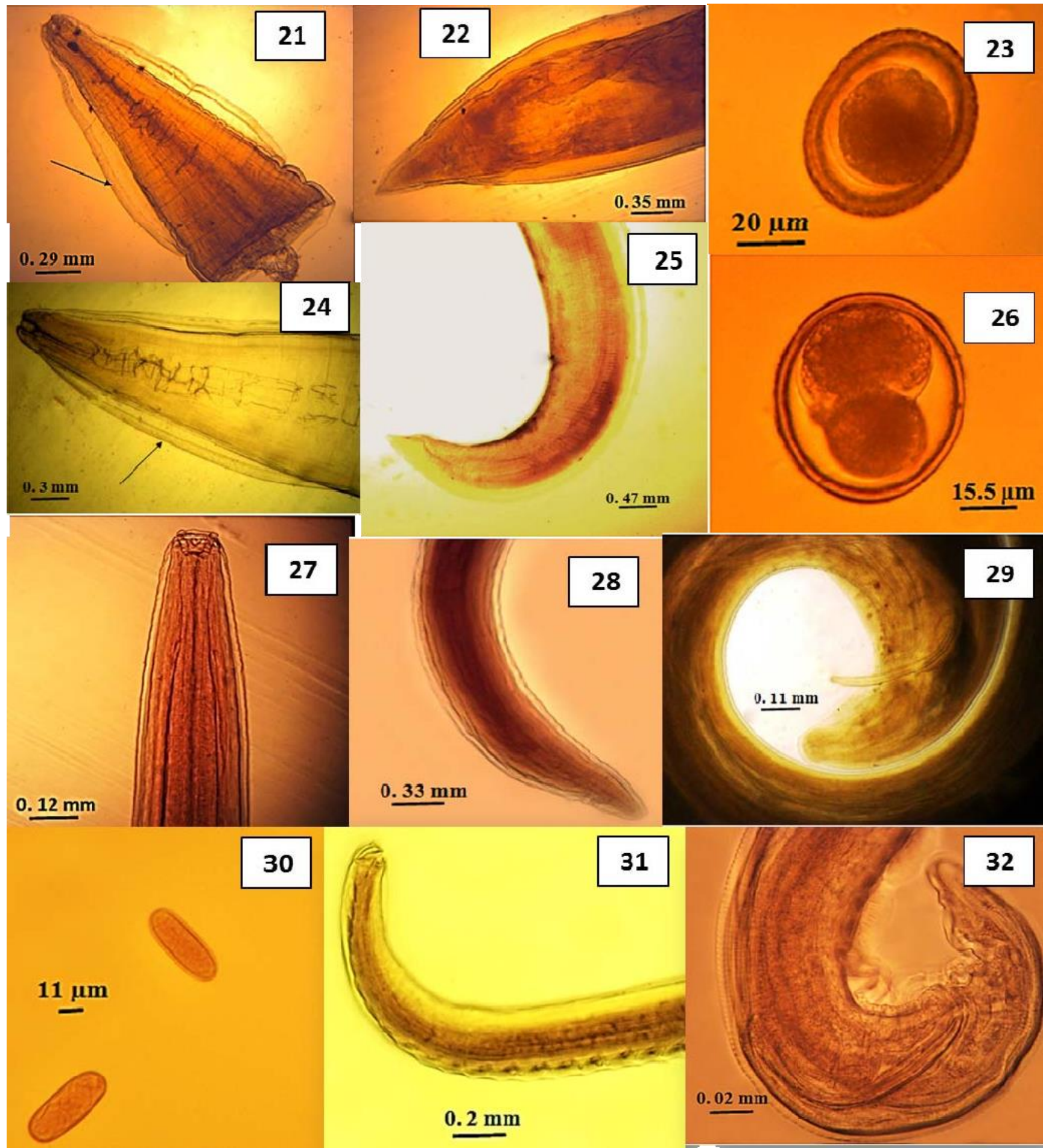

Figure 21-32: Nematodes of stray dogs in Ismailia City

21: Toxocara canis anterior end

22: Toxocara canis female posterior end

23: Toxocara canis eggs

24: Toxascaris leonina anterior end

25: Toxascaris leonina male posterior end

26: Toxascaris leonina egg

27: Spirocerca lupi anterior end

28: Spirocerca lupi female posterior end

29: Spirocerca lupi male posterior end

30: Spirocerca lupi egg

31: Rictularia affinis anterior end

32: Rictularia affinis male posterior end 
As shown in Table (3), the frequency of mixed infection with helminths (70\%) was higher than that of the single infection (30\%). All necropsied dogs were infected with at least one zoonotic helminth parasite. The zoonotic helminths were one nematode (Toxocara canis), one cestode species (Dipylidium caninum) and seven trematodes (Prohemistomum vivax, Heterophyes dispar, Phagicola longus, Pygidiopsis summa, Metagonimus yokogawai, Apophallus donicus, and Haplorchis pumilio).

In tables $4 \& 5$, the Chi-square analysis of the prevalence of different helminths in relation to the age and sex of dogs revealed that there was a highly significant difference ( $p \leq 0.01$ ) in the prevalence of trematodes and $T$. canis in relation to the age of dogs. However, there was no significant difference $(p>0.05)$ in the prevalence of Taenia hydatigena, Toxascaris leonina, Spirocerca lupi, and Rictularia affinis in relation to the age of dogs. No significant difference ( $p>0.05$ ) was found in the prevalence of helminths between dogs of different sexes.
Table 3: The frequency of single, multiple, and zoonotic infection

\begin{tabular}{lcc}
\hline \multicolumn{1}{c}{ Helminthes } & $\begin{array}{c}\text { No. of infested/no. of } \\
\text { examined }\end{array}$ & $\%$ \\
\hline Single infection & $15 / 50$ & 30 \\
Mixed infection & $35 / 50$ & 70 \\
Two helminth species & $10 / 50$ & 20 \\
Three helminth species & $5 / 50$ & 10 \\
Four helminth species & $5 / 50$ & 10 \\
More than four species & $15 / 50$ & 30 \\
Zoonotic infection & $50 / 50$ & 100 \\
\hline
\end{tabular}

\section{Histopathological alterations:}

The lungs of dogs infected with Spirocerca lupi showed pulmonary alveolar emphysema, with focal mononuclear cell infiltration and granuloma formation (Fig. 33-34). The oesophagus of Spirocerca lupi-infected dogs revealed focal aggregations of mononuclear cells, with marked fibrosis, granulation tissue formation, and early fibroma (Fig. 35-38).

Table 4: Chi-square analysis of the prevalence of different helminths in relation to the age of dogs

\begin{tabular}{|c|c|c|c|c|c|}
\hline Helminthes & Age & No. of infested/ no. of examined & Prevalence (\%) & $\mathrm{X}^{2}$ & p-value \\
\hline Trematodes & $\begin{array}{l}\text { Young } \\
\text { Adult }\end{array}$ & $\begin{array}{c}0 / 20 \\
18 / 30\end{array}$ & $\begin{array}{c}0.0 \\
60.0\end{array}$ & 16.24 & $0.00^{* *}$ \\
\hline Dipylidium caninum & $\begin{array}{l}\text { Young } \\
\text { Adult }\end{array}$ & $\begin{array}{l}20 / 20 \\
30 / 30\end{array}$ & $\begin{array}{l}100.0 \\
100.0\end{array}$ & NA & NA \\
\hline Taenia hydatigena & $\begin{array}{l}\text { Young } \\
\text { Adult }\end{array}$ & $\begin{array}{l}0 / 20 \\
5 / 30\end{array}$ & $\begin{array}{c}0.0 \\
16.7\end{array}$ & 2.08 & 0.15 \\
\hline Toxocara canis & $\begin{array}{l}\text { Young } \\
\text { Adult }\end{array}$ & $\begin{array}{l}8 / 20 \\
2 / 30\end{array}$ & $\begin{array}{c}40.0 \\
6.7\end{array}$ & 6.38 & $0.01^{* *}$ \\
\hline Toxascaris leonina & $\begin{array}{l}\text { Young } \\
\text { Adult }\end{array}$ & $\begin{array}{l}4 / 20 \\
1 / 30\end{array}$ & $\begin{array}{c}40.0 \\
3.3\end{array}$ & 2.08 & 0.15 \\
\hline Spirocerca lupi & $\begin{array}{l}\text { Young } \\
\text { Adult }\end{array}$ & $\begin{array}{l}0 / 20 \\
5 / 30\end{array}$ & $\begin{array}{c}0.0 \\
16.7\end{array}$ & 2.08 & 0.15 \\
\hline Rictularia affinis & $\begin{array}{l}\text { Young } \\
\text { Adult }\end{array}$ & $\begin{array}{l}0 / 20 \\
4 / 30\end{array}$ & $\begin{array}{c}0.0 \\
13.3\end{array}$ & 1.37 & 0.24 \\
\hline
\end{tabular}

* significant difference $p \leq 0.05, * *$ highly significant difference $p \leq 0.01$, NA: not applicable

Table 5: Chi-square analysis of the prevalence of different helminths in relation to dog sex

\begin{tabular}{|c|c|c|c|c|c|}
\hline Helminthes & Sex & No. of infested/ no. of examined & Prevalence (\%) & $\mathrm{X}^{2}$ & p-value \\
\hline \multirow[t]{2}{*}{ Trematodes } & Male & $10 / 23$ & 43.5 & 0.52 & 0.47 \\
\hline & Female & $8 / 27$ & 29.6 & & \\
\hline \multirow[t]{2}{*}{ Dipylidium caninum } & Male & $23 / 23$ & 100.0 & NA & \\
\hline & Female & $27 / 27$ & 100.0 & & NA \\
\hline \multirow[t]{2}{*}{ Taenia hydatigena } & Male & $3 / 23$ & 13.0 & 0.04 & 0.85 \\
\hline & Female & $2 / 27$ & 7.4 & & \\
\hline \multirow[t]{2}{*}{ Toxocara canis } & Male & $4 / 23$ & 17.4 & 0.01 & 0.94 \\
\hline & Female & $6 / 27$ & 22.2 & & \\
\hline \multirow[t]{2}{*}{ Toxascaris leonina } & Male & $3 / 23$ & 17.4 & 0.04 & 0.85 \\
\hline & Female & $2 / 27$ & 22.2 & & \\
\hline \multirow[t]{2}{*}{ Spirocerca lupi } & Male & $1 / 23$ & 4.3 & 0.57 & 0.45 \\
\hline & Female & $4 / 27$ & 14.8 & & \\
\hline \multirow[t]{2}{*}{ Rictularia affinis } & Male & $1 / 23$ & 4.3 & 0.12 & 0.72 \\
\hline & Female & $3 / 27$ & 11.1 & & \\
\hline
\end{tabular}

* significant difference $p \leq 0.05, * *$ highly significant difference $p \leq 0.01$, NA: not applicable 

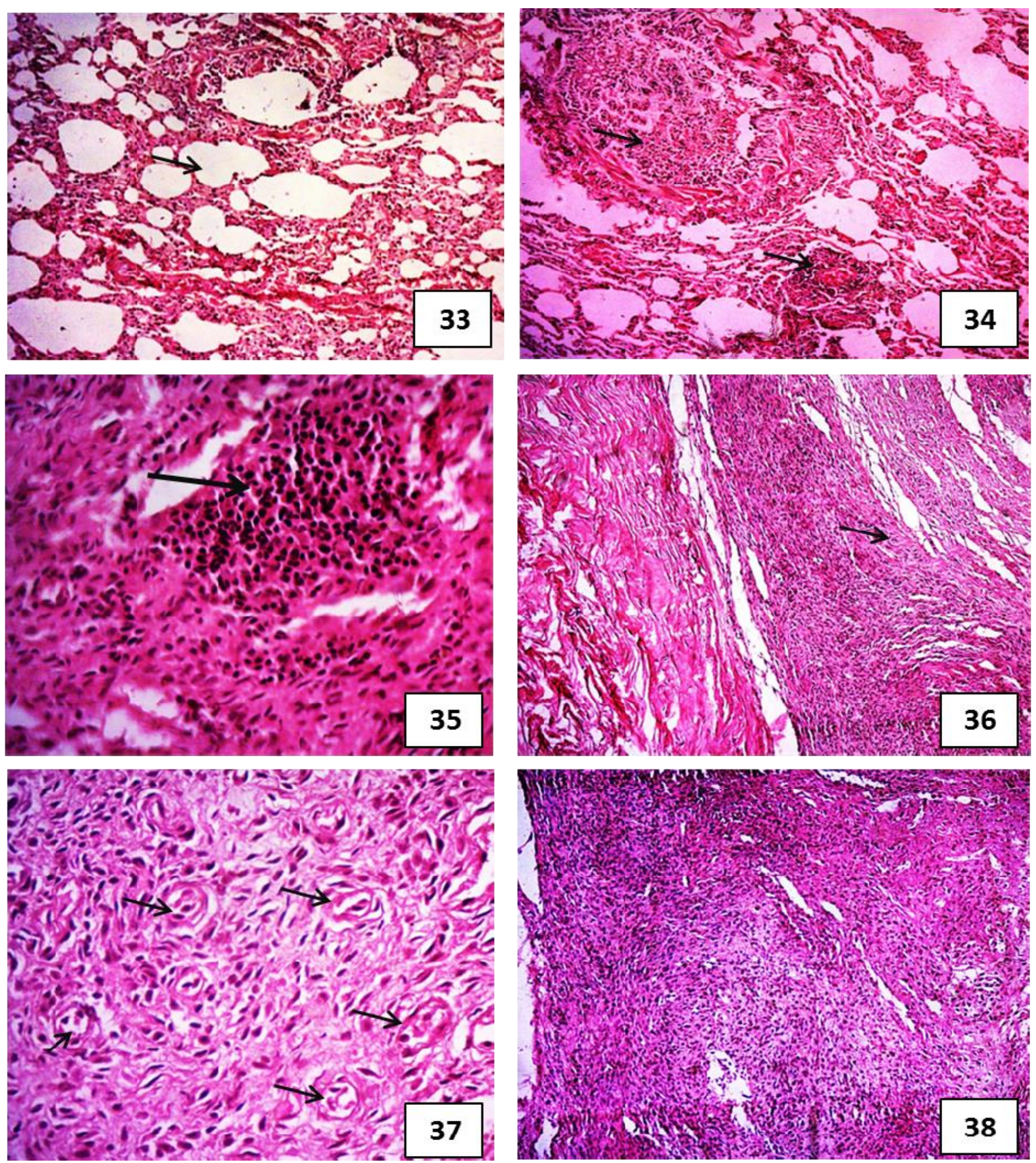

Figure 33-38: Histopathological alterations of lungs and oesophagus of dogs infected with Spirocerca lupi H\&E

stain33: Lung showing pulmonary alveolar emphysema with focal mononuclear cells infiltration

34: Lung showing a chronic inflammatory reaction with granuloma formation (arrows)

35: Oesophagus showing focal aggregations of mononuclear cells (arrow)

36: Oesophagus showing chronic inflammatory reactions with marked fibrosis (arrow)

37: Oesophagus showing granulation tissue with newly formed capillaries (arrows)

38: Oesophagus showing proliferation of fibroblasts in a characteristic form of early fibroma 


\section{Discussion}

This study was carried out on 50 stray dogs, and 20 helminth parasites were detected. The total prevalence of helminths was $100 \%$, similar to El-Gayar (2005) (100\%) in Ismailia City, Jones et al. (2011) (100\%) in Ethiopia, and Traub et al. (2002) (99\%) in northeastern India. However, a lower prevalence was recorded by Abd-Alla (2002) (86.2\%), Adamu et al. (2012) (13.8\%), and Adinezadeh et al. (2013) (84\%). The total prevalence of trematodes was $36 \%$, higher than that recorded by Abd-Alla (2002) (13.79\%) and El-Gayar (2005) (13.3\%). The total prevalence of cestodes was $100 \%$, higher than that recorded by Abd-Alla (2002) (86.2\%) and El-Gayar (2005) (73\%). The total prevalence of nematodes was $34 \%$, higher than that reported by Mehrabani et al. (2002) (24.8\%) in Iran but lower than that reported by Abd-Alla (2002) (55.17\%), El-Gayar (2005) (46.6\%), and Yacob et al. (2007) (95\%) in Ethiopia.

The detected trematodes during this study were Prohemistomum vivax (4\%), Mesostephanus appendiculatus (16\%), Mesostephanus melvi (6\%), Mesostephanus sp. (2\%), Echinochasmus liliputans (16\%), Heterophyes dispar (14\%), Pygidiopsis genata (20\%), Pygidiopsis summa (4\%), Ascocotyle rara (4\%), Phagicola longus (6\%), Phagicolla longicollis (4\%), Metagonimus yokogawai (4\%), Haplorchis pumilio (6\%), and Apophallus donicus (4\%). These trematodes were previously recorded singly or collectively by several authors; Fahmy and Selim (1959), Selim (1967) in Cairo and Giza Governorates, Vanparijs \& Thienpont (1973) in Belgium, Massoud et al. (1981) in Iran, Fahmy et al. (1984) in Assiut province, Nieddu \& Lochi (1988) in Italy, Ibrahim et al. (1989) in Assiut province, El-Seify \& Nabih (1998) in Giza Governorate, Abd-Alla (2002) in Zagazig City, El-Gayar (2005) in Ismailia City and Wang et al. (2006) in China. Pygidiopsis summa and Ascocotyle rara were recorded for the first time in Ismailia province, and this may be the first time to be recorded among Egyptian dogs. Pygidiopsis summawas firstly detected in dogs fed on brackish water fish infected with the metacercariae in Japan (Onji \& Nishio, 1916). Pygidiopsis summa is also prevalent in the Republic of Korea (Chai \& Lee, 2002). The descriptions and measurements of the detected trematodes were matched to those of Fahmy \& Selim (1959), Kuntz \& Chandler (1956), Fahmy \& Selim (1959), Yamaguti (1939), Fahmy et al. (1984), and Niemi \& Macy (1974). Prohemistomum vivax was differentiated from Mesostephanus spp. by the absence of a caudal dorsal appendage, and the body was oval and not bipartite rather than elongated (Yamaguti, 1939). Mesostephanus appendiculatus was differentiated from M. melvi, which possesses a visible oesophagus and an elongated, clubshaped cirrus pouch and lacks a vaginal sphincter. Moreover, the gonads were in the middle of the body in Mesostephanus appendiculatus but posteriorly in $M$. melvi (El-Gayar, 2007). Pygidiopsis genata was differentiated from $P$. summa by the presence of a small posterior appendage on the oral sucker of $P$. summa (Skrjabin, 1964) and the presence of spines on gonotyl in $P$. summa. The ceca of $P$. genata reached the level of the ovary, turning slightly dorsomedial at the terminal portion, while in P. summa extended down to the level of anterior of testes and had distended ends instead of turning medially (Chai et al., 1986b). The ventral sucker was nearly round and globular in Pygidiopsis genata but constantly elliptical, transversely oblique, and sub-median in $P$. summa. Phagicola longicollis was differentiated from $P$. longa by the following: the body was much more elongate; the pharynx was situated at a considerably greater distance from the anterior end in $P$. longicollis than in $P$. longa; the ventral sucker in $P$. longicollis was round and smaller $(49 \mu \mathrm{m})$, whereas that in $P$. longa was elongate $(70 \mu \mathrm{m})$; and the oral sucker was armed with 14 or 15 spines compared with 16 spines in P. longa (Kuntz \& Chandler, 1956). The present specimens of Ascocotyle rara were compared to Ascocotyle mcintoshi, recorded by El-Seify \& Nabih (1998). Ascocotyle rara could be differentiated by its larger size and the absence of excretory bladder compared to the laterally branched voluminous excretory bladder of A. mcintoshi (Yamaguti, 1958). Kuntz \& Chandler (1956) attributed the variation in the prevalence of trematodes infesting dogs to the variation in localities from which dogs were collected and to the season during which dogs were exposed to infestation. In our opinion, the available food, such as fish, frogs, and snakes, could also play an essential role in the occurrence and prevalence of digenetic trematodes in dogs in this study. The present study revealed a highly significant difference $(p<0.01$ ) in the prevalence of trematodes between different ages $160 \%$ in adults and $0 \%$ in young dogs). This difference might be related to the availability of intermediate hosts to adults due to the free-roaming character of adult stray dogs, exposing these animals to fish offal infected with encysted metacercariae.

Regarding cestodes, Dipylidium caninum was recorded in $100 \%$ of examined dogs. This data agreed with the results of Selim (1967), who reported that D. caninum is 
the most prevalent tapeworm in Egyptian dogs. This result was higher than that recorded by El-Gayar (2005) (73\%), El Menyawe \& Abdel Rahman (2007) (5\%), Umar (2009) (75.0\%), Pestechian et al. (2012) (22.9), Nabavi et al. (2014) (7.2\%) and Gugsa et al. (2015) (72.72\%). The intensity of Dipylidium caninum was 62.3 (2-189) worms/ dog, lower than that of Xhaxhiu et al. (2011) (2-309), but higher than that of Wang et al. (2006) (1-96), Umar (2009) (5-6) and Eslami et al. (2010) (1) worm/dog. This high prevalence and intensity of $D$. caninum could be attributed to the high prevalence of fleas and lice, the intermediate hosts of those worms among stray dogs in Ismailia City. The prevalence of Taenia hydatigena was $10 \%$, nearly like that of Pestechian et al. (2012) (13.5\%), higher than that reported by Eguía-Aguilar et al. (2005) (2.5\%), but lower than that reported byAdinezadeh et al. (2013) (61\%), Nabavi et al. (2014) (28.6\%) and Gugsa et al. (2015) (63.63\%). The intensity of T. hydatigena was 2 (1-4) worms/dog, which agreed with that of Umar (2009) (5-6), Eslami et al. (2010) (2-4), and Gugsa et al. (2015) (4), while lower than that reported by Wang et al. (2006) (1-14), Dai et al. (2009) (1-17) and Xhaxhiu et al. (2011) 5.1 (1-38) worms/dog. However, no significant difference in the prevalence of $T$. hydatigena in relation to age was found in this study. Taenia hydatigena prevalence in adult dogs $(16.7 \%)$ was higher than in young $(0 \%)$. This finding was most probably because of the longer exposure of older dogs to the source of infection and the longevity of the worms (Adinezadeh et al., 2013).

The prevalence of Toxocara canis was 20\%, nearly similar to that of Minnaar et al. (2002) (21\%), Yacob et al. (2007) (21\%), and Eslami et al. (2010) (22\%), higher than that reported by El-Gayar (2005) (10\%), Umar (2009) (6.3\%), Pestechian et al. (2012) (6.3\%), and Adinezadeh et al. (2013) (7\%), but lower than that recorded by El Menyawe \& Abdel Rahman (2007) (39.2\%), Xhaxhiu et al. (2011) (75.7\%), and Abere et al. (2013) (39.8\%). The intensity of Toxocara canis was 7.3 (3-15) worms/dog, nearly similar to that of Xhaxhiu et al. (2011) 8.3 (1-54), while higher than that reported by Umar (2009) (2-4) and Eslami et al. (2010) (1-2) but lower than that reported by Wang et al. (2006) (1-72) and Dai et al. (2009) (1-100). There was a highly significant difference $(p=0.01)$ in the prevalence of Toxocara canis in the current study with the age of dogs (40\% in young dogs and $6.7 \%$ in adult ones). This result was consistent with previous studies (Gholami et al., 2011; Das et al., 2012; Abere et al., 2013). The agerelated difference in the prevalence could be explained by the transmission pattern of this nematode (mainly by transplacental and transmammary routes) and the acquired age-dependent immunity caused by repeated exposure (Gillespie \& Pearson, 2001). The prevalence of Toxascaris leonina was $10 \%$, nearly like that of El-Gayar (2005) (6.7\%) and Razmi et al. (2006) (6\%), higher than that recorded by Gholami et al. (2011) (2\%) and Xhaxhiu et al. (2011) (0.9\%), but lower than that reported by Dai et al. (2009) (32.3\%), Pestechian et al. (2012) (21.9\%) and Adinezadeh et al. (2013) (53\%). The intensity of Toxascaris leonina was 4.4 (2-8) worms/dog, similar to that of Xhaxhiu et al. (2011) (4), but lower than that reported by Dai et al. (2009) (1-56). This variation in the prevalence and intensity of Toxascaris leonina can be attributed to the age effect (Urquhart et al., 1996).

The prevalence of Spirocerca lupi was 10\%, approaching that of Minnaar et al. (2002) (13\%) in South Africa and Gholami et al. (2011) (6\%) in Iran and lower than that recorded by Das et al. (2011) (40\%) in Bangladesh, Perera et al. (2013) (22.2\%) in Sri Lanka, and Gugsa et al. (2015) (72.7\%) in Ethiopia. Our results revealed that Spirocerca lupi intensity was 5.6 (3-8) worms/dog, slightly lower than that recorded by Gugsa et al. (2015) (9.13). The high prevalence of spirocercosis could be attributed to the large number of wandering stray dogs and the ease of contact with poultry offal and insects/beetles (Das et al., 2011). In the present study, the oesophagus of dogs infested with $S$. lupi exhibited focal aggregations of mononuclear cells, with marked fibrosis, granulation tissue formation, and early fibroma. This result agreed with that reported by MazakiTovi et al. (2002) and Ranen et al. (2004). The prevalence of Rictularia affinis was $8 \%$, higher than that recorded by Gholami et al. (2011) (2\%) in the north of Iran and Pestechian et al. (2012) (3.13\%) in Isfahan but lower than that recorded by Dalimi et al. (2006) (12.5\%) in the west of Iran. Rictularia affinis was previously recorded by AbdelAal (1990) in foxes in the Sinai Area, but this was the first time to be recorded in dogs in Ismailia province. The prevalence of $R$. affinis depends on the availability of cockroaches and entomophagous vertebrates, such as lizards (intermediate and paratenic hosts), as food sources (Zare-Bidaki et al., 2010).

Here, mixed helminth infection with two or more different species was more common (70\%) than infection with one species. These results agree with that of Eslami et al. (2010) (mixed infection, 80\%) in Iran, Jones et al. (2011) (mixed infection, 84.6\%) in Ethiopia, Paulos et al. (2012) 
(mixed infection, 81\%) in Ethiopia, and Perera et al. (2013) (mixed infection $73.3 \%$ ) in Sri Lanka. The most likely explanation for the high prevalence of mixed parasitic infections in this study is that stray dogs act as scavengers and do not receive regular veterinary care (Paulos et al., 2012). There was no significant difference ( $p>0.05)$ in the prevalence of detected helminths between sexes, consistent with previous works (Awoke et al., 2011; Abere et al., 2013; Onyeabor, 2014).

In the present study, all the necropsied stray dogs harbored at least one zoonotic helminth (100\%), in agreement with Traub et al. (2002) (99\%) and Dalimi et al. (2006) (100\%), but higher than that reported by Costin et al. (2011) (61.9\%). Dipylidium caninum accidentally infects human beings, especially children or those in close contact with dogs. The zoonotic nematode recorded in this study was Toxocara canis, which produces a condition known as visceral larva migrans (VLM) in children and ocular migrans in adult human beings (Gavignet et al., 2008). We detected seven trematodes (Prohemistomum vivax, Heterophyes dispar, Pygidiopsis summa, Phagicola longus, Metagonimus yokogawai, Apophallus donicus, and Haplorchis pumilio) previously recorded in humans. Nasr (1941) reported the first case of human infestation with $P$. vivax in Egypt. Human infections with $H$. dispar were reported in two Korean men who returned from Saudi Arabia (Chai et al., 1986a) and Thailand (Yu \& Mott, 1994). Human infections with $P$. summa were first reported in Japan by detecting eggs in feces (Takahashi, 1929) and adult flukes in the human intestine (Yokogawa et al., 1965). Additionally, Chai \& Lee (1990) detected $P$. summa in humans in Korea. Human infections with $P$. longus were reported in Brazil (Chieffi et al., 1992). Metagonimus yokogawai is probably the most common intestinal fluke infecting humans in the Far East (Chai \& Lee, 2002). Human infections with $M$. yokogawai were reported in Korea (Chai \& Lee, 1990), the northern provinces of Siberia, Israel, the Balkan states, and Spain (Yu \& Mott, 1994). Experimental human infection with Apophillus donicus was successful in the United States of America (Niemi \& Macy, 1974). There were other reports of infection with this species in humans where fish are eaten raw (Schell, 1985). Human infections with Haplorchis pumilio were reported in the Philippines, Thailand, Laos, South China, Taiwan, and Egypt (Yu \& Mott, 1994).

In conclusion, stray dogs in Ismailia City carry a multitude of helminth parasites, thus posing a threat to the human population and companion dogs.

\section{REFERENCES}

Abd-Alla, A.R.A. (2002): Some Studies on Parasites of Dogs. M.V.Sc. Thesis, (Parasitology). Fac. Vet. Med. Zagazig Univ. Abdel Aal (1990): Some studies on the helminthes parasites of wild animals in Sinai Area. MVSc. Thesis, (Parasitology). Fac. Vet. Med. Suez Canal Univ.

Abere, T.; Bogale, B. and Melaku, A. (2013): Gastrointestinal helminth parasites of pet and stray dogs as a potential risk for human health in Bahir Dar town, north-western Ethiopia. Vet. World, 6(7): 388-392.

Adamu, N.B.; Adamu, J.Y. and Salisu, L. (2012): Prevalence of ecto-, endo- and haemoparasites in slaughtered dogs in Maiduguri, Nigeria. Revue Méd. Vét., 163(4): 178-182.

Adinezadeh, A.; Kia, E.B.; Mohebali, M.; Shojaee, S.; Rokni, M.B.; Zarei, Z. and Mowlavi, G. (2013): Endoparasites of Stray Dogs in Mashhad, Khorasan Razavi Province, Northeast Iran with Special Reference to Zoonotic Parasites. Iran. J. Parasitol., 8(3): 459-466.

Awoke, E.; Bogale, B. and Chanie, M. (2011): Intestinal Nematode Parasites of Dogs; Prevalence and Associated Risk factors. Int. J. Anim. Vet. Adv., 3(5): 334-374.

Beck, A.M. (2000): The human-dog relationship: a tale of two species. In: Macpherson CNL, Meslin FX, Wandeler AI (eds) Dogs, zoonoses and public health. CABI, Wallingford. Pp: 1-16.

Bwalya, E.C. (2012): A survey on endoparasites of dogs in Lusaka and Katete districts of Zambia. M.V.Sc. Thesis, (Infectious diseases). Univ. Zambia, Lusaka.

Chai, J.Y. and Lee, S.H. (1990): Intestinal trematodes of humans in Korea: Metagonimus, heterophyids and echinostomes. Korean J. Parasitol., 28: 103-122.

Chai, J.Y. and Lee, S.H. (2002): Food-borne intestinal trematode infections in the Republic of Korea. Parasitol. Int., 51: 129-154.

Chai, J.Y.; Seo, B.S.; Lee, S.H.; Hong, S.J. and Sohn, W.M. (1986a): Human infections by Heterophyes heterophyes and $H$. dispar imported from Saudi Arabia. Korean J. Parasitol., 24: 82-88.

Chai, J.Y.; Seo, B.S.; Lee, S.H. and Hong, S.T., (1986b): Growth and development of Pygidiopsis summa in rats and mice with a supplementary note on its morphological characters. Korean J. Parasitol., 24: 55-62.

Chieffi, P.P.; Gorla, M.C.O.; Torres, D.M.; Dias, R.M.; Maggini, A.C.S.; Monteiro, A.V.M. and Woiciechovski, E. (1992): Human infection by Phagicola sp. (Trematoda: Heterophyidae) in the municipality of Registro, Sao Paulo State, Brazil. J. Trop. Med. Hyg., 95: 346-348.

Costin, I.I.; Enăchescu, V.; Ciopaşiu, R.; Ioniţă, M. and Mitrea, I.L. (2011): Prevalence of endoparasites, by coproscopical examination, on dogs from some urban and rural areas in south of Romania. Lucrari Stiintifice Universitatea de Stiinte Agricole a Banatului Timisoara, 
Medicina Veterinara , 44(1): 31-37.

Dai, R.S.; Li, Z.Y.; Li, F.; Liu, D.X., Liu, W.; Liu, G.H.; et al. (2009): Severe infection of adult dogs with helminthes in Hunan Province, China poses significant public health concerns. Vet. Parasitol., 160: 348-350

Dalimi, A.; Sattari, A. and Motamedi, G. (2006): A study on intestinal helminthes of dogs, foxes, and jackals in the western part of Iran. Vet. Parasitol., 142(1-2): 129-133.

Das, S.; Alim, M.A.; Hassan, M.M.; Sikder, S.; Muraduzzaman and Masuduzzaman, M. (2011): Spirocercosis in stray dogs of Chittagong Metropolitan area of Bangladesh: an epidemiological and pathological investigation. Vet. World, 4(11): 485-491.

Das, S.; Alim, M.A.; Sikder, S.; Gupta, A.D.; Masuduzzaman, M. (2012): Prevalence and Worm Load of Enteric Helminthiasis in Stray Dogs of Chittagong Metropolitan, Bangladesh. YYU Veteriner Fakultesi Dergisi, 23(3): 141-145.

Drug, R.A.; Wallington, E.A. and Cancerson, R. (1967): Carleton's Histopathological techniques. Fourth Ed. Oxford Uni. Press, London, New York, Toronto.

Eguía-Aguilar, P.; Cruz-Reyes, A. and Martinez-Maya, J.J. (2005): Ecological analysis and description of the intestinal helminthes present in dogs in Mexico City. Vet. Parasitol., 127: 139-146.

El-Gayar, A. K. (2005): The prevalence of some parasites of stray dogs in Ismailia City. EVMSPJ., 11(2): 383-400.

El-Gayar, A. K. (2007): Studies on some trematode parasites of stray dogs in Egypt with a key to the identification of intestinal trematodes of dogs. Vet. Parasitol., 144: 360-365.

El Menyawe, S.M. and Abdel Rahman, M.A.M. (2007): The role of dogs and cats in transmitting some parasites to man in Cairo Governorate. EVMSPJ., 4(1): 735-756.

El-Seify, M.A. and Nabih, A.M. (1998): Some studies on helminthes infesting dogs. I-Incidence among dogs in Giza Governorate. In: Eighth Scientific Congress, Fac. Vet. Med. Assiut University. 387-427.

Eslami, A.; Ranjbar-Bahadori, S.; Meshgi, B.; Dehghan, M. and Bokaie, S. (2010): Helminth Infections of Stray Dogs from Garmsar, Semnan Province, Central Iran. Iran. J. Parasitol., 5(4): 37-41.

Fahmy, M.A.M. and Selim, M.K. (1959): Studies on some trematode parasites of dog in Egypt with special reference to the role played by fish in their transmission. $\mathrm{Z}$. Parasitenkol., 19: 3-13.

Fahmy, M.A.M.; Arafa, M.S.; Khalifa, R.; Abdel-Rahman, A.M. and Mounib, M.E. (1984): Studies on helminth parasites in some small mammals in Assiut Governorate. ITrematode parasites. Assiut. Vet. Med. J., 2: 43-50.

Fleck, S.L. and Moody, A. H. (1993): Diagnostic Techniques in Medical Parasitology. ELBS. with Buttetworth-Heinemann, Publishers, London

Gavignet, B.; Piarroux, R.; Aubin, F.; Millon, L. and Humbert, P. (2008): Cutaneous manifestations of human toxocariasis. J. Am. Acad. Dermatol., 59(6): 1031-1042.
Gholami, I.; Daryani, A.; Sharif, M.; Amouei, A. and Mobedi, I. (2011): Seroepidemiological survey of helminthic parasites of stray dogs in Sari City, northern Iran. Pak. J. Biol. Sci., 14(2): 133-137.

Gillespie, S.H. and Pearson, R.D. (2001): Principles and Practice of Clinical Parasitology. John Wiley \& Sons, Ltd.

Gugsa, G.; Hailu, T.; Kalayou, S.; Abebe, N. and Hagos, Y. (2015): Prevalence and Worm Burdens of Gastrointestinal Parasites in Stray Dogs of Mekelle City, Tigray, Ethiopia. American-Eurasian J. Agric. \& Environ. Sci., 15(1): 08-15.

Ibrahim, M.K.; Mahmoud, A.Z. and Khalifa, R. (1989): Pathological changes associated with Haplorchis pumilio (looss, 1896); an intestinal trematode of dogs. Assiut Vet. Med. J., 21: 94-97.

Jones, O.; Kebede, N.; Kassa, T.; Tilahun, G. and Macias, C. (2011): Prevalence of dog gastrointestinal parasites and risk perception of zoonotic infection by dog owners in Wondo Genet, Southern Ethiopia. J. Public Health and Epidemiology, 3(11): 550-555.

Kuntz, R.E. and Chandler, A.C. (1956): Studies on the Egyptian trematodes with special reference to the heterophyids of mammals. I. Adult flukes with description of Phagicola longicollis n sp. Cynodiplostomum n. sp. and Stephanora from cats. J. Parasitol., 42: 445-459. Massoud, J.; Jalali, H. and Reza, M. (1981): Studies on trematodes of the family heterophyidae (Odhner, 1914) in Iran: 1. Preliminary epidemiological surveys in man and carnivores in Khuzestan. J. Helminthol., 55 (4): 255-260. Mazaki-Tovi, M.; Baneth, G.; Aroch, I.; Harrus, S.; Kass, P.H.; Ben-Ari, T.; Zur, G.; Aizenberg, I.; Bark H. and, E. (2002): Canine spirocercosis: clinical, diagnostic, pathologic, and epidemiologic characteristics. Vet. Parasitol., 107: 235-250.

McManus, D.P. (2006): Molecular discrimination of taeniid cestodes. Parasitol. Int., 55: 31-37.

Mehrabani, D.; Sadjjadi, S.M. and Oryan, A. (2002): Prevalence of gastrointestinal nematode parasites in stray dogs in Shiraz, Southern Iran. J. Appl. Anim. Res., 22: 157160

Minnaar, W.N.; Krecek, R.C. and Fourie, L.J. (2002): Helminthes in dogs from a peri-urban resource-limited community in Free State Province, South Africa. Vet. Parasitol., 107: 343-349.

Nabavi, R.; Naeini, K.M.; Zebardast, N. and Hashemi, H. (2014): Epidemiological Study of Gastrointestinal Helminthes of Canids in Chaharmahal and Bakhtiari Province of Iran. Iranian J. Parasitol., 9(2): 276-281.

Nabih, A.M. (1998): Some studies on helminthes infesting dogs. Ph.D. Thesis, Fac. Vet. Med., Kafr El-Sheikh, Tanta Univ., Egypt.

Nasr, M. (1941): The occurrence of Prohemistomum vivax infection in man, with redescription of the parasite. Lab. Med. Prog., 2: 135-149.

Nieddu, A.M. and Lochi, P.G. (1988): Heterophydi e ospiti intermedi in Sardegna. Riv. Parassit., 49: 261-267. 
Niemi, D.R. and Macy, R.W. (1974): The life cycle and infectivity to man of Apophallus donicus (Skrjabin and Lindtrop, 1919) (Trematoda: Heterophyidae). Proc. Helminthol. Soc. Washington, 41: 223-229.

Onji, Y., and Nishio, T. (1916): On the trematodes whose intermediate host is brackish water fishes. Chiba Igaku Semmon Gakko Zasshi, 81\&82; 229-24

Onyeabor, A. (2014): Prevalence of Gastrointestinal Helminthes of Dogs: A Retrospective Study. J. Vet. Adv., 4 (11): 746-751.

Paulos, D.; Addis, M.; Fromsa, A. and Mekibib, B. (2012): Prevalence of gastrointestinal helminthes among dogs and owners perception about zoonotic dog parasites in Hawassa Town, Ethiopia. Journal of Public Health and Epidemiology, 4(8): 205-209.

Perera, P.K., Rajapakse, R.P.V. J. and Rajakaruna, R.S. (2013): Gastrointestinal parasites of dogs in Hantana area in the Kandy District. J. Natn. Sci. Foundation Sri Lanka, 41 (2): 81-91.

Pestechian, N.; Rasouli, A. and Yoosefi, H.A. (2012): Distribution of Intestinal Worms among Stray Dogs in Isfahan, Iran. Journal of Isfahan Medical School, 29(173): 1.

Ranen, E.; Lavy, E.; Aizenberg, I.; Perl, S. and Harrus, S. (2004): Spirocercosis associated esophageal sarcomas in dogs. A retrospective study of 17 cases (1997-2003). Vet. Parasitol., 119: 209-221.

Razmi, G.R.; Sardari, K. and Kamrani, A.R. (2006): Prevalence of Echinococcus granulosus and other intestinal helminthes of stray dogs in Mashhad area, Iran. Archives of Razi Institute, 61(3): 143-148.

Rhindali, L.; Biggeri, A.; Carbon, S.; Musella, V.; Catelon, D.; Venziano, V. and Cringoli, G. (2006): Canine fecal contamination and parasitic risk in the City of Naples (Southern Italy). BMC Vet. Res., 2: 29.

Salb, A.L.; Barkema, H.W.; Elkin, B.T.; Thompson, R.C.A.; Whiteside, D.P.; Black, S.R.; Dubey, J.P. and Kutz, S.J. (2008): Dogs as sources and sentinels of parasites in humans and wildlife, Northern Canada. Emerg. Inf. Dis., 14: 60-63.

Schell, S.C. (1985): Handbook of Trematodes of North America North of Mexico. Idaho: University Press of Idaho.

Selim, M.K. (1967): Studies on some helminth parasites infesting dogs in Cairo and Giza. J. Egypt. Med. Assoc., 27: 37-48.

Skrjabin, K.I. (1964): Keys to the Trematodes of Animals and Man. University of Illinois Press, Urbana.

Snedecor, G.W. and Cochran, W.G. (1991): Statistical Methods (Eighth Ed.). Journal of the American Statistical Association, 86(415): 834.
Soulsby, E.J.L. (1982): Helminthes, arthropods, and protozoa of domesticated animals. Seventh Ed. Lea \& Febiger, Philadelphia.

Takahashi, S. (1929): On the eggs of Stellantchasmus falcatus and Pygidiopsis summus found in human stools. Okayama Igakkai Zasshi, 41: 1502-1513.

Traub, R.J.; Robertson, I.D.; Irwin, P.J.; Mencke, N. and Thompson, R.C.A.A. (2002): The role of dogs in transmission of gastrointestinal parasites in a remote teagrowing community in northeastern India. Am. J. Trop. Med. Hyg., 67(5): 539-545.

Umar, Y. A. (2009): Intestinal Helminthoses in Dogs in Kaduna Metropolis, Kaduna State, Nigeria. Iran. J. Parasitol., 4(1): 34-39.

Urquhart, G.M.; Armour, J.L.; Dunn, A.M. and Jennings, F.W. (1996): Veterinary Parasitology fifth Ed., Longman Scientific and Technical, UK.

Vanparijs, O. F. J. and Thienpont, D. C. (1973): Canine and feline helminth and protozoan infections in Belgium. J. Parasitol., 59(2): 327-330.

Wang, C.R.; Qiu, J.H.; Zhao, J.P.; Xu, L.M.; Yu, W.C. and Zhu, X.Q. (2006): Prevalence of helminthes in adult dogs in Heilongjiang Province, the People's Republic of China. Parasitol. Res., 99: 627-630.WSPA (2009): Stray animals. In: World Society for the Protection of Animals.

Xhaxhiu, D.; Kusi, I.; Rapti, D.; Kondi, E.; Postoli, R.; Rinaldi, L.; et al. (2011): Principal intestinal parasites of dogs in Tirana, Albania. Parasitol. Res., 108: 341-353.

Yacob, H.T.; Ayele, T.; Fikru, R. and Basu, A.K. (2007): Gastrointestinal nematodes in dogs from Debre Zeit, Ethiopia. Vet Parasitol., 148: 144-148.

Yamaguti, S. (1939): Studies on the helminth fauna of Japan. Part 25 trematodes of birds 4. Jap. Zool. 7: 129210.

Yamaguti, S. (1958): Systema helminthes . Vol. I, Digenetic trematodes of vertebrates. Interscience Publisher. London.

Yokogawa, M.; Sano, M.; Itabashi, T. and Kachi, S. (1965): Studies on the intestinal flukes II. Epidemiological studies on heterophyid trematodes of man in Chiba. Prefecture. Jpn. J. Parasitol., 14: 577-585.

Yu, S.H. and Mott, K.E. (1994): Epidemiology and morbidity of food-borne intestinal trematode infections. Trop. Dis. Bull., 91: 125-152.

Zare-Bidaki, M.; Mobedi, I.; Ahari, S.S.; Habibizadeh, S.; Naddaf, S.R. and Siavashi, M.R. (2010): Prevalence of Zoonotic Intestinal Helminthes of Canids in Moghan Plain, Northwestern Iran. Iranian J. Parasitol., 5(2): 42-5. 